\title{
Cultural and Traditional Sport Pacu Jalur Location in Regency of Quantan Singingi Riau Province
}

\author{
Alta Febra ; Sugiyanto Sugiyanto; Agus Kristiyanto; \\ Sebelas Maret University \\ Email: febrafc07@gmail.com
}

http://dx.doi.org/10.18415/ijmmu.v5i4.293

\begin{abstract}
This research was conducted in Kuantan Singingi Regency of Riau Province. This research is descriptive qualitative interpretative research with the subject of research is the origin of culture and traditional sport pacu jalur, traditional tour and sport of the pacu jalur, and what values are contained in the traditional sport of the pacu jalur. Data collection techniques include observation, in-depth interviews, and documentation of records. The results are summarized as follows: 1) The origins of traditional culture and sport, have existed since the Dutch era. Initially Pacu Jalur was held in villages around the Kuantan River to commemorate the big day of Islam, such as the Prophet's Mawlid, Idul Fitri and the Islamic New Year. However, after the Dutch entry into Indonesia, Pacu jalur changed the function that is to commemorate the Queen's Anniversary Wihelmina. The pacu jalur was not held during the Japanese colonial era. After the era of Indonesian Independence, Pacu jalur was again held to commemorate the Independence Day of the Republic of Indonesia. Therefore, Pacu Jalur always held around August every year. Pacu jalur has become the official agenda of the Regional Government (Pemda) and has been included in the national tourism calendar. Initially this pacu jalur is only commemorated at religious events only, namely the religious event of Islam maulid prophet. But with the development, the pacu jalur is no longer displayed at religious events only; 2) The tours contained in the culture of pacu jalur is the night market, pacu jalur expo, festipal art area; 3 ) What values are contained in the pacu jalur, the value of adaptation to nature, where the pacemakers must adapt to the river, the value of art and culture is evident from the carvings, track paints and clothing or uniforms of the pacu jalur, the economic value seen at the time of manufacture the pacu jalur that does not cost a bit and the value of sport is seen from the movement of the paddle paddle racing boy and the strength of arms and hands with great enthusiasm.
\end{abstract}

Keywords: Pacu Jalur; Values; Culture Tour; Sport Traditional; River; Taluk Kuantan;

\section{Introduction}

The background of this research is the culture of pacu jalur in Kuantan Singingi regency a cultural tradition that has lasted from the colonial era until now the tradition is pacu jalur. This pacu jalur is held annually in commemoration of Independence Day of the Republic of Indonesia. This pacu jalur tradition is not only included in the cultural agenda of Riau Province but has been included in the national cultural tourism agenda. Culture khasanah from Kuanatan Singingi is not lost by the time and can be 
maintained from generation to generation. The pacu jalur is a traditional rowing boat sporting from Riau. Boat on the race pacu jalur has a length of about 25-40 meters with a boat crew of 40-60 people.

The result of the culture of the Kuantan Bay community (Kuantan Singingi), the pacu jalur is a complex of ideas or ideas of the community's actions. (Uu Hamidi., 1996) said the above also implies that the pacu jalur is one form of the whole complex of understanding, belief and art, law, customs and all the capabilities of the Kuantan Bay community.

This type of research is a qualitative research with phenomenology approach. The feonomenology method in this study was adapted from Cresweel. According to (Creswell., 1998), the phenomenological approach delayed all judgments about natural attitudes until found a certain basis. This delay is called epoche (time period). The epoche concept is to distinguish the data area (subject) by the interpretation of the researcher. The epoche concept is central to where researchers construct and classify early guesses about phenomena to understand what respondents are saying. The steps of phenomenological research conducted Creswell namely: 1) Observation; 2) In-depth Interview; 3) Documentation.

Based on the stages above the main objectives of this study are 1) Identify cultural origins and traditional sports pacu jalur; 2) Identify the tourism contained in traditional culture and sports pacu jalur; 3) Identify what values are contained in the pacu jalur.

Indonesia is an archipelago consisting of many islands and has various tribes, languages, customs and culture. The cultural diversity found in Indonesia is a proof that Indonesia is a country rich in cultures. So on the basis that all forms of regional culture will be very influential on national culture, and vice versa national culture derived from the local culture, will be very influential also on local culture or local culture. Culture is a wealth that has the values-a value that is characteristic of a region also be a symbol of the personality of a nation or region, because culture is a wealth and characteristic of a region, then maintaining, maintaining and preserving culture is an obligation of each individual to be guarded and preserved by every tribe.

Kuantan Singingi is an area that is administratively included in Riau Province. The area has many rivers. Such geographical conditions, in turn, make most of the people need a path as a means of transportation. Then, there are beautifully carved jalur, such as snake head carvings, crocodiles, or tigers, both in the stomach and the bay. In addition, coupled with umbrella equipment, ropes, scarves, middle pole (gulang-gulang) and waving (where the helmsman standing). This change also marks the development of the function of the jalur becomes not just a means of transport, but also shows a social identity. Because, only the ruler of the region, nobles, and datuk-datuk who ride the ornate jalur. The next development (approximately 100 years later), the path not only serves as a means of transportation and a person's social status symbol but contested speed through a race. And, the race by the community called Pacu Jajur.

Culture pacu jalur in Kuantan Singingi regency is a cultural tradition that has lasted from the colonial era until now, the tradition is the pace of the pacu jalur. This pacu jalur is held annually in commemoration of the Independence Day of the Republic of Indonesia. This pacu jalur tradition is not only included in the cultural agenda of Riau Province but has been included in the national cultural tourism agenda. Pacu jalur has a cultural significance contained therein, namely tenacity, cooperation, hard work, agility and sportsmanship. the repertoire of Kuantan singing culture is not lost by time and can be defended from the generation of generation. Pacu jalur activity has become a tour for people kuantan singingi who want to see the jalur that compete, not even the people kuantan singingi only but the tourists abroad that is Singapore, Malaysia, many also came to see the pacu jalur. 
Sport is a systematic and planned activity to improve physical, spiritual and mental fitness. The purpose of national sports according to law no. (Keolahragaan., 2005) is a national sport aims to maintain and improve health and fitness as well as a means of improving human achievement and quality, instilling moral values and noble character, sportsmanship, discipline, unifying and fostering unity and unity.

The orientation of building a sport is to build an educational sport, build a sports achievement, and build a recreational sport. Only then will the actual sports development goals be achieved effectively (Agus Kristiyanto., 2012). As mandated in the 1945 Constitution, the national sport aims to maintain and improve the health and fitness of achievement, human quality, inculcate moral values and noble morals, discipline sportsmanship, mernpererat and fostering unity and strengthening the nation's unity national security, and raising the dignity, dignity, and honor of the nation.

Cultures that have many aspects of Culture in terms of Art, Language, Traditional House, Sports, Games and Traditions must remain in their own path of existence. In this era of Globalization that threatens many cultures in the World especially in Indonesia, this is due to the many cultures of Indonesia and the number of population in Indonesia can make faded cultural culture In Indonesia. This should be the attention of the government and also the residents to keep doing the tradition or culture in this country. Many of the attention in Indonesia is like in the admission of our culture by other countries or even disappear in place because there is no awareness to do tradition traditions that exist in our country.

Many games are also a sport that disappears due to factors from within and outside ourselves of our country. The influence of technology that advocates the development of Globalization is also a factor driving the loss of our own culture. Culture or tradition in Indonesia such as games and traditional sports became my concern because many children in Indonesia who do not even know how to play it and the rules of the rules. Art is a culture that can be maintained because art can form its own space in the development of globalization, as in the case of the entertainment world that can be a container of traditional Indonesian art. In this case I will discuss about the traditional games and sports that exist in Indonesia and also the influence on other things that exist in this Indonesian culture.

Traditional sport is a cultural diversity that needs to be preserved. This is because traditional games or sports have the same position in order to preserve, nurture and even develop elements that are closely related to the customs and traditions of a particular group of people. According to (Uhamisastra., 2010) the traditional game is: "a game full of noble values and norms useful for adults to understand and seek balance in the order of life.

The game is one of the activities that exist in learning PJOK. According (Sukintaka., 1998) mentions that when children play or given a game in learning PJOK then the child will do the game with pleasure. Because of this pleasure then the child will reveal the original personality when they play, whether it is original thoughts and habits that have shaped his personality. Thus, it can be said that through play, children can do as much movement in their activities as well as they can show the identity or habits that exist within the child.

Playing and playing is an indispensable activity for human life. Every human being basically requires playing activities not only to enhance physical development, but also social, intellectual and emotional. Indeed, the term play is more inherent in the lives of children, but that does not mean adults do not need play activities (Dkk., 2018). According to (Satria., 2016) traditional game is a game that has been played children in a certain area traditionally, the tradition here is that this game has been inherited from generation berkutnya. Can be concluded a traditional game is a game that children do in decreasing with unofficial rules. 


\section{Methodology}

1) This type of research is a qualitative study according to Spradley in Sugiyono (Sugiyono., 2013) states that "qualitative research does not use the term population, but by Spradley is called" social situation "or social situation consisting of three elements: place, actors), and activity (activity) that interact synergistically. Moleong (2013) argues that "qualitative research is essentially an attempt to find the truth or to justify the truth." This qualitative research method is used to find facts with appropriate interpretation, accurate and valid in describing the nature, action and tendency of certain group or individual phenomena in the empirical level.

2) The hermeneutic model, according to (Raharjo., 2008) "which in English is hermeneutics, comes from the Greek words hermeneuine and hermeneia which respectively mean 'interpret' and 'interpretation'.

\section{Result and Discussion}

Kuantan Singingi or Kuansing regency is one of the districts in Riau Province of Indonesia. Kuansing regency is also known as rantau Kuantan or as an overseas area of Minangkabau people (Rantau nan Tigo Jurai). In everyday life, Kuansing people use customs and Minangkabau language. This regency is located in the southwest part of Riau Province and is an expansion of Indragiri Hulu Regency. Kuantan Singingi Regency is tropical. The rainy season lasts from September to February and the highest rainfall in December. Dry season from March to August.

Kuantan Singingi Regency consists of lowland and highlands approximately $400 \mathrm{~m}$ above sea level. The highlands in this area tend to be windy and hilly with a 5-300 tendency. The hilly highlands reach a height of 400-800 m above sea level and are part of the ranks of hill ranks. There are two major rivers that cross the Kuantan Singingi regency of Kuantan River and Singingi River. The role of the river is very important, especially as a means of transportation, clean water sources, aquaculture and can be used as an artificial resource to produce hydroelectric power supply. Watershed area of Kuantan River flows 9 (nine) sub-districts of Hulu Kuantan sub-district, Kuantan Mudik sub-district, Gunung Toar subdistrict, Kuantan Tengah sub-district, Benai sub-district, Pangean sub-district, Kuantan Hilir sub-district, Inuman sub-district and Cerenti sub-district.

\section{The Origin of Cultural and Traditional Sports Pacu Jalur}

Initially Pacu Jalur was held in villages around the Kuantan River to commemorate the big day of Islam, such as the Prophet's Mawlid, Idul Fitri and the Islamic New Year. However, after the Dutch entry into Indonesia, Pacu jalur changed the function that is to commemorate the Queen's Anniversary Wihelmina. The runway was not held during the Japanese colonial era. After the era of Indonesian Independence, Pacu jalur was again held to commemorate the Independence Day of the Republic of Indonesia. Therefore, Pacu Jalur always held around August every year. Pacu jalur has become the official agenda of the Regional Government (Pemda) and has been included in the national tourism calendar. Initially this pacu jalur is only commemorated at religious events only, namely the religious event of Islam maulid prophet. But with the development, the pacu jalur is no longer displayed at religious events only.

River boat is a means of water transportation which is very vital for the life of Kuantan singingi people, especially those who live in the river area. One type of river boat is the path. In the Great Indonesian Dictionary (Poerwadarminta., 2003), the word jalu is defined as a small boat made from a tree. Meanwhile, in the Malay dialect of Kuantan people the word path is defined as a boat that has a length of 
approximately 25 to 30 meters and a width of approximately 1 to 1.5 meters. The path in the sense of Kuantan society is made from a log tree without being split or cut or cut. Understanding the jalur referred to by the KBBI and Kuantan community above does seem contradictory. However, these two meanings have relevance when viewed from the history of the development of the jalur itself. Since the beginning of the 17th century AD, when land transportation was undeveloped, the boats were the main means of transportation for rantau communities in Rantau Kuatan, especially for those living along the Kuantan River between Hulu Kuantan Subdistrict in the upstream to Cerenti subdistrict.

In the beginning, the type of boat used by the Kuantan community is called a small kenek boat with a length of about 2-2.5 meters, width $60 \mathrm{~cm}$, and $2 \mathrm{~cm}$ thick. This one-person boat is commonly used as a private means of transportation to the fields to cut/ snare the sap or rubber. In addition, this boat is also used for fishing, fishing (catching fish with a kind of small net), and stomping (a kind of fishing gear with fishing rods attached to floating) In the further development, Kuantan people create larger boats that called a loaded boat, which is a boat that can carry four people. This type of boat is commonly used for fishing fish and transporting rice and other crops. Furthermore, they create again a type of boat called a mine boat. The mine is a local language that means the cost or the cost So the boat that can carry about 8 to 15 people is used as a means of public transportation by the local community from one village to the village opposite each other on the riverbank.

After that, the Kuantan community created a boat called a godang perahu boat that is about 15-20 meters long and 1-1.5 meters wide. This one-tonne boat is used to transport crops such as rubber, coconut, sugarcane, and commodities (such as rice, sugar, flour). This boat is then the embryo of the creation of a larger boat size, which is now commonly known by the name of the jalur. This type of boat has a length of about 25-30 meters with a width of about 1.5 meters. It is not known exactly when this jalur was created. However, it is certain that the jalur became popular among the Kuantan people around the early 19 th century.

In terms of shape and size, the line is smoother, leaner, and longer than the godang boat. The traditional boat Kuantan community is also equipped with long bow and rudder, as well as an elegant carved to give the beauty of the jalur. In addition to being the crown of a jalur, a rowing serves as a place for the hand of the onjoi (rhythm maker to move the jalur). The shape of the jalur is increasingly developed with various forms of carvings such as snake head carvings, crocodiles, or tigers, both in the stomach and selembayung. In addition, the line is also equipped with umbrellas, ropes, scarves, and gulang-gulang (middle pole). The change marked the development of the function of the jalur not just a means of conveyance, but also to show the social identity for the one who drove it. This ornate jalur is driven only by regional rulers, nobles, and datuk-datuk (Anonymous, wikipedia).

\section{The Tours Contained in Traditional Culture and Sports Pacu Jalur}

Once the Pacu jalur is completed and the match equipment has been completed. So the Pacu Jalur Festival was held in Sungai Kuantan. Usually before the National Pacu jalur Festival is held, the first District Pacu jalur Festival is held. District Pacu jalur Festival started to be held for 2 months in various subdistricts ahead of National Pacu jalur. Then the top event is the National pacu jalur Festival held in August every year.

\section{a. Opening Ceremony}


The opening ceremony is an event where the opening of the Pace jalur opening ceremony precisely held in the field of Limuno Bay of Kuantan City. In this event there are several cultural performances, such as Line Dance, Dance Offering or Carano Dance. It will also be inaugurated or opened with some remarks from local officials, chief executives, governors or even vice presidents. A few years ago, the opening of the Pace jalur Festival was inaugurated by vice president Jusuf Kalla. The opening ceremony was held in the morning on the first day of the Pace jalur Festival.

\section{b. Core Event}

The core event was conducted on the same day after the opening ceremony. The core event was held at noon at around 14.00 WIB precisely in the Arena Pacu jalur is the Edge of Narosa Bay of Kuantan City. The core event is the real event, where all the jalur will be pitted. Usually the participating jalur always exceeds 100 jalur. Can you imagine how busy the Kuantan River at that time. In the core event is composed again of some custom process that must be done by every jalur and its players, namely:

First, every lane will be on the edge of the Kuantan River, precisely near the pacu jalur/ mooring jalur as I have mentioned above. Then there will be each jalur prepared first completeness as well as every player. Secondly, all players warm up first and then proceed to read prayer and listen to some direction by partuo and shaman jalur. After that, all players will fill the jalur in accordance with their respective duties. The jalur is ready to be rowed and getting ready at the start of the stake.

Third, the line is preparing to wait for the call from the Pacu jalur organizing committee. Then the 2 jalur to be opposite will be called by the jury, then the two jalur must immediately get ready to race.

Fourth, flag waves will soon appear and cannon blast will soon be heard if the second jalur Strip is in the same position at stake start. This marks the start of the game for both the jalur called to contest. Then both jalur raced endlessly until the pancang finish.

Fifth, after the two races are raced up to the stake, all players will shake hands with one player on the opposing track and proceed to the adjoining judge/ judge stand. Then the jury will soon announce which route will be the winner of the match. Sixth, every jalur that has known to win or lose is based on the announcement by the jury, the jalur will be rowed to return home to the lane moor. That's the sixth sequence of processes that every jalur will undergo until all the jalur finish. Every jalur that wins the match on the first day, will be back in the lot for the second day in the morning so that in the afternoon can return to the match. So next to get the winners of the Pacu jalur Festival.

\section{c. Closing Ceremony}

The closing ceremony is the final event of the entire series of Pacu jalur Festival events. This event is usually done on the last day (fourth day) Festival Pacu Jalur. The closing ceremony is usually held at night, precisely in the Garden City jalur Kuantan Bay. In the event there is also a variety of entertainment and traditional events. And most importantly on that night will be distributed prizes for all winners (usually up to 15). The prizes always vary in number each year. But certainly, the champions will get prizes of livestock and millions of dollars. The amount or amount of prizes vary for each rank. And the most important prize is the Rotating Cup and Fixed Cup. The Cup is still earned if a jalur won the First Prize for 3 consecutive years.

\section{d. Tour Event}


When the Pacu jalur Festival is held, there are also a series of other events that can be met, including:

\section{Night Market}

In the night market you can find a variety of arena games such as those available on the night market in general. In addition, my friend can also shop cheap that night. And most importantly, my friend can buy Kuansing special food and buy goods that exist only during the Pacu jalur Festival takes place, including the Pacesetched track suitcase, trajectory Pacu jalur, and my friend will also find a miniature of the jalur that compete. Buddy can select it based on the jalur you paled on.

\section{Pacu Jalur Expo}

In Pacu jalur Expo you will find everything related to Pacu Jalur. Buddy will get an explanation of Pacu Jalur and all concerned with Kuansing, such as culture, customs, traditional arts, and so forth.

\section{Regional Arts Festival}

In addition to visiting the night market and pacu jalur expo, my friend also watched local festival art in the evening. In the festival is contested by several dances, music, and various art of Kuantan Singingi.

\section{What Values Are Contained in the Pacu Jalur}

The jalur is not just a means of transportation or a race boat, but more than that, it is the cultural heritage of the Kuantan Singingi ancestors who are full of values- These values include:

\section{a. Adaptation Value}

Close to nature, economic value, social, art, religious, and tourism. Adaptation value. The presence of the pacu jalur is the result of Kuantan community adaptation to the surrounding natural conditions traversed by two major rivers. Such conditions provide inspiration or imagination for them to create a jalur as a means of river transportation.

\section{b. Value of Proximity to Nature}

The Kuantan community is known for its proximity to nature. This can be seen from the use of environmentally friendly building materials because it is made from natural wood which grows in many forests in the area.

\section{c. Economic Value}


Jalur is one of the most vital means of transportation in the economic life of the Kuantan people. The line is used as a means of transportation to fish in the river and go to the fields, as well as a means of transportation to distribute various types of crops. Thus, the existence of the jalur becomes one of the important factors in improving the economic life of Kuantan Singingi people in Riau.

\section{d. Art Value}

Jalur is the creation of Kuantan people who have high aesthetic value. Through the touch of skilled hands of the community, the long, large logs can be "transformed" into a lean and beautiful jalur. The value of the estitics on the jalur is also evident in its rowing which is given various carving motifs with high carving technique.

\section{e. Social Value}

A form of social value is seen in the process of making the path. Starting from the beginning to the end of the process always carried out in a cooperative and voluntary. All the energy and cost necessary to make a jalur become the responsibility of the whole community in a village.

\section{f. Tourism Value}

The presence of the lane becomes the main attraction for the local and foreign tourists who come to Kuantan Singingi. This jalur became one of the means of the race in the festival known as the race track. The festival is now one of the pride tourism event Kuantan Singingi regency, Riau Province.

\section{Conclusion}

Based on the findings of field data and theoretical discussions, this research can summarize the following:

First the origin of cultural and traditional sports pacu jalur starting since 1900 AD in the Dutch colonial era. The Dutch admitted the excitement of this pathway when they began to enter the quarry area of Kuantan around 1905. They took advantage of the pacu jalur to celebrate Queen Wihelmina's Anniversary which falls on every August 31st. It is no longer celebrated on Muslim big days. New pacu jalur activity began to provide prizes to the winners in 1905. A century of pacu jalur fell in 2003 ago, until now pacu jalur was 114 years old.

Sports pacu jalur is a kind of traditional rowing boat sport that comes from Riau. Boat on the race runway has a length of about 25-40 meters degan boat crew as much as 40-60 people. Now the pacu jalur event has entered into the national tourism calendar every year on 23-26 August held the pacu jalur festival in order to commemorate the Independence Day of the Republic of Indonesia.

Both tours are found in the traditional culture and sports of the night market, pacu jalur expo, regional art festival.

Third Value contained in the pacu jalur, the value of adaptation, the value of proximity to nature, economic value, art value, social value, tourism value.

\section{Suggestion}


Based on the conclusions and implications that have been described above, then the advice of the author is as follows:

a) All elements of society, especially the quanta rantau community, should provide support and encouragement to the young generation of the future to preserve the cultural heritage of the ancestors.

b) The tourism office is expected to further promote the traditional sport of this pacu jalur, not only used as an icon dripada Kuantan Singingi regency but also made a unique and memorable tour for the local and foreign tourists. As long as traditional sports and our culture are preserved by the next regeneration.

c) The forestry service should pay more attention to the management of the forest especially the protected forest because the basic material of the jalur is large wood. Without good forest management the traditional sport of the pacu jalur is unlikely to be preserved by the next generation. Given up to now the more aged Abad aged traditional sports pacu jalur.

d) The youth and sports department is expected to participate actively and observe in the selection of athletes so that the athlete or better known to the race child is chosen according to the board's expectations. With the ability and propesionalitas work in the field of athlete nursery owned by the relevant offices for the sake of the generation of quality jalur children from year to year.

\section{References}

Agus Kristiyanto. (2012). pembangunan olahraga untuk kesejahteraan rakyat dan kejayaan bangsa. Surakarta: Yuma Pustaka.

Creswell, J. W. (1998). Qualitative inquiry and research design: Choosing among five traditions. Qualitative Health Research. California: Sage Publication. https://doi.org/10.1111/1467-9299.00177.

Dkk, effendi anggara dan hartati yuli. (2018). Permainan Tradisional Terhadap Minat Siswa Dalam Mengikuti. Surabaya: Fakultas Ilmu Keolahragaan Universitas Negeri Surabaya. Jurnal Pendidikan Olahraga dan Kesehatan. Volume. 06. Nomor. 01. Hal. 45-49.

Keolahragaan, undang undang. (2005). Tentang Sistem Keolahragaan Nasional Kementrian Negara Pemuda Dan Olahraga Republik Indonesia. indonesia.

Moleong, L. (2013). Metodology Penelitian Kualitatif. Bandung: PT. Remaja.

Poerwadarminta, W. j. (2003). Kamus Umum Bahasa Indonesia. Jakarta: Balai Pustaka.

Raharjo, M. (2008). Dasar-Dasar Hermeneutika Antara Intensionalisme Dan Gadamerian. Yogyakarta: Ar-ruzz Media Group.

Satria, R. O. dan H. Y. (2016). Penerapan Permainan Tradisional Terhadap Partisipasi Akif Siswa. Surabaya: Fakultas Ilmu Keolahragaan Universitas Negeri Surabaya. Jurnal Pendidikan Olahraga dan Kesehatan. Volume. 04. Nomor. 02. Hal. 295-300. 
Sugiyono. (2013). Metode Penelitian Pendidikan Pendekatan Kuantitaif, Kualitatif, dan R\&D. Metode Penelitian Pendidikan Pendekatan Kuantitaif, Kualitatif, Dan R\&D. Bandung: Alfabeta. https://doi.org /10.1007/s13398-014-0173-7.2.

Sukintaka. (1998). Teori Bemain untuk Pendidikan Jasmani. Yogyakarta: Yogyakarta IKIP: FPOK.

Uhamisastra. (2010). Pengertian Permainan Tradisional. http://repository.upi.edu/operator/upload/s_sdp_0701129_chapter1.pdf [April, 2013: http://repository.upi.edu/operator/upload/s_sdp_0701129_chapter1.pdf [April, 2013.

Uu Hamidi. (1996). Dukuh Melayu Rantau Kuantan Riau. Pekanbaru: Departemen Pendidikan dan Kebudayaan.

\section{Copyrights}

Copyright for this article is retained by the author(s), with first publication rights granted to the journal.

This is an open-access article distributed under the terms and conditions of the Creative Commons Attribution license (http://creativecommons.org/licenses/by/4.0/). 